DOI: 10.1515/ausp-2016-0020

\title{
On the Hungarian Equivalents of the English Passive in Literary Translations A Case Study on the Translations of Two Novels
}

\author{
Enikő TANKÓ \\ Sapientia Hungarian University of Transylvania (Miercurea Ciuc, Romania) \\ Department of Humanities \\ tankoeniko@csik.sapientia.ro
}

\begin{abstract}
This paper investigates the choice of Hungarian equivalents for the English passive construction in translated texts in order to have a glimpse on how translators deal with the English passive. In previous studies (Tankó 2011, 2014), we have looked at the problems encountered by L1 speakers of Hungarian in the acquisition of the English passive voice, having identified different Hungarian equivalents of the English passive that native speakers would resort to when expressing a passive meaning. A special attention has been paid to the Hungarian predicative verbal adverbial construction, which seems to be the closest syntactic equivalent of the English passive, which captures most of its syntactic or discourse function properties. The main question to pursue is whether L1 speakers of Hungarian use the same strategies as shown in previous studies or they choose some other structures to express the passive meaning when it comes to translating literary texts. On the other hand, we would like to analyse Hungarian contexts which require a translation using the passive in English. Thus, our corpus consists of Orwell's 1984 and Jókai Mór's Az arany ember, comparing them with their translated versions.
\end{abstract}

Keywords: translation, passive construction, translation equivalent

\section{Introduction}

The primary aim of this paper is to investigate the choice of Hungarian equivalents for the English passive construction in translated texts. Furthermore, we wish to compare the strategies translators would resort to when translating literary texts with the choices of L1 speakers in their everyday speech.

In the first part of the paper, we will present the translation equivalents which were associated with the English passive by L1 speakers of Hungarian, and then enlist the hypothesis of our research. We will continue by providing an analysis 
of the data resulting from the two novels and their translated versions, followed by discussions and conclusions.

\section{Previous studies}

In previous studies (Tankó 2011, 2014), we have identified several Hungarian equivalents of the English passive construction, which evince at least one of the parametric properties of English passive sentences. These structures are: (i) the synthetic passive, (ii) the third person plural form of the verb with generic reading, (iii) the active sentence with the direct object in topic position or (iv) the active sentence with the direct object in topic and the subject in focus position, and $(\mathrm{v})$ the predicative verbal adverbial construction. In what follows, we will analyse them one by one, looking at their main characteristics.

\subsection{The synthetic passive}

There used to be a synthetic (verbal) passive in Old Hungarian, formed with the suffix -tat/-tet. In the codices, these passive forms are used very frequently (Tóth 2000: 253). However, they occur extremely rarely in contemporary Hungarian, and only with certain verbs. For example: születik ('be born', from szül 'give birth'), adatik ('be given', from ad 'give'), viseltetik ('owe somebody certain feelings', from visel 'bear'), foglaltatik ('be included', from (magába) foglal 'include'). It must also be mentioned that, although used, most of these forms (except for születik) are considered archaic.

\subsection{The $3^{\text {rd }}$ person plural form of the active verb}

In Hungarian, the active verb forms are not only used in the active sense (e.g. He closed the door.) and in the unaccusative sense (e.g. The door closed.) but also to express passive meaning (e.g. The door was closed by Mike.) by using the third person plural form of the active verb where the agent remains unexpressed.

(1) Felszeletelik a kenyeret.

prt $_{\mathrm{UP}}$. slice:3rd.pl the bread.Acc

'They slice the bread. / The bread is sliced.'

As remarked in previous studies, an interesting feature of the structure is that it can be used even in cases when only one agent is meant (i.e. The bread is sliced by one woman). Thus, the structure has a generic reading. In this respect, the structure resembles the English short passives. 


\subsection{Active sentence with the direct object in topic}

Although a regular active sentence, the direct object appears pre-verbally, that is in an emphatic position. When topicalized, the DO is extracted from the verbal phrase and occupies a position at the left periphery of the sentence.

(2) Az ajándékot megvásároltam.

the present.Acc prt $_{\mathrm{MEG}}$.buy:past.1sg

'I have bought the present.'

Compared to the passive in English, it is the topicalization of the internal object that occurs in both the English passive and the Hungarian active sentence with the direct object in topic position. The active verbal form is not altered, and the external object is kept as the subject. Only the internal object moves in topic position. However, it retains the accusative case, as opposed to the passive voice in English. Thus, the active sentence with the direct object in topic position is an equivalent which resembles the English long passives.

\subsection{Active sentence with the direct object in topic and the subject in focus position}

Similarly to the previous construction, the direct object is topicalized. Furthermore, the subject too appears in an emphatic position on the left periphery of the sentence, i.e. it is in focus position, carrying the main accent.

\section{Ezt a tortát ÉDESANYÁM sütötte.}

this the cake.Acc mother.my bake.past.3sg

'This cake has been made by my mother.'

Compared to the passive in English, just like in the active sentence with the direct object in topic, it is the topicalization of the internal object that occurs in both the English passive and the Hungarian active sentence with the direct object in topic and the subject in focus position. Again, the active verbal form is not altered, and the external object is kept as the focused subject. Thus, the active sentence with the direct object in topic and the subject in focus position is an equivalent which resembles the English long passives where the agent is focused on since it brings along some new information. 


\subsection{The predicative verbal adverbial construction}

In contemporary Hungarian, the predicative verbal adverbial construction (PVAC) is sometimes referred to as passive, or passive-like construction (see Alberti 1996, 1998; Márkus 2008, among others). It is true that the PVAC appears to be a syntactic equivalent of the passive, for a number of reasons: (i) it disposes of a special verbal phrase (the adverbial participial form, ending in -vA), (ii) it implies an auxiliary (van 'to be' or lett/lesz 'become'), (iii) it selects the internal argument as subject, and (iv) it may overtly express the agent. However, the Hungarian PVAC, due to numerous constraints, has a low productivity, as opposed to the passive in English.

(4) Az autó le van fest-ve.

the car ${ }_{\text {Nom }}$ prt $_{\text {down }}$ is paint-vA

'The car has been painted.'

(5) Az autó le lett fest-ve a fiú által.

the $\mathrm{car}_{\mathrm{Nom}}$ prt $_{\text {down }}$ became paint-VA the boy by

'The car got painted by the boy.'

In what follows, we will present the constraints on the two types of PVAC in Hungarian. There are (i) lexical constraints regarding the class of verbs which can appear in the construction; (ii) aspectual constraints (especially regarding telicity); and (iii) syntactic constraints regarding the presence/absence of an overtly expressed agent phrase in the two types of PVAC.

As for the lexical constraint, only transitive and ergative (unaccusative) verbs are compatible with the PVAC (Kertész 2005: 2).

(6) A kávé meg van órölve.

the coffee PRT be:3sg grind.adv.part

'The coffee has been ground.'

(7) A tó be van fagyva.

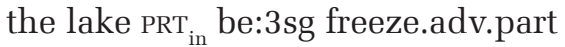

'The lake is frozen.'

(8) *Mari énekelve van.

Mary sing.adv.part be:3sg

*'Mary is sung.' (Kertész 2005: 2)

From an aspectual point of view, states and processes are incompatible with the PVAC, as the first class of verbs lacks any change of state; furthermore, they are not telic. It is only aspectually complex verbs that occur in the PVAC (i.e. accomplishments and achievements), as they can be decomposed into a process and a resulting state, thus affecting the implied subject. 
(9) * Az esó zuhogva van.

the rain pour.adv.part be:3sg

'The rain is pouring.'

(10) A levél meg van írva.

the letter PRT be:3sg write.adv.part

'The letter has been written.'

(11) Az üveg el van pattanva.

the glass PRT ${ }_{\text {away }}$ be:3sg crack.adv.part

'The glass is cracked.' (Kertész 2005: 16-17)

Thirdly, concerning the syntactic constraint, the adverbial participle form describes a state which came about as a result of the event expressed by the base verb; consequently, it cannot be interpreted as eventive. This is why an important characteristic of the be-PVAC is that no by-phrase can appear to express the agent of the action. On the other hand, the PVAC with the auxiliary lett/lesz 'become' is grammatical with an overtly expressed agent phrase, as illustrated below.

* A fal le van fest-ve a fiú által.

the wall PRT ${ }_{\text {down }}$ is paint-vA the boy by

'The wall is painted by the boy.' (Tóth 2000: 242)

A fal a fiú által lett lefestve.

the wall.Nom the boy by become:3.sg.past prt $_{\text {Down }}$. paint.vA

'The wall has been painted by the boy.'

Another consequence of the stative reading of the be-PVAC is that it not compatible with manner adverbials, for example quickly, which can only modify events. In contrast, the PVAC with the auxiliary lett/lesz 'become' is grammatical with the same type of adverbs.

* A levél gyorsan van meg-ír-va.

the letter quickly is PRT -write-vA

'The letter is written quickly.' (Tóth 2000: 241)

* A levél gyorsan lett meg-ír-va.

the letter quickly become PRT -write-vA

'The letter got written in a hurry.'

Concluding, there are several types of constraints which apply for the Hungarian PVAC. Basically, it is mainly transitive or ergative verbs, accomplishments or achievements which are compatible with this construction, while the agent depends on the choice of the auxiliary since only the PVAC with the auxiliary lett/lesz 'become' allows the presence of a by-phrase. 


\subsection{Findings of previous studies}

In previous studies, we have analysed the frequency of the above enumerated structures, all of them resembling to some extent the English passive construction. The results of the empirical research have shown that for perfective verb forms and short passives test subjects tend to use the PVAC, while progressives and long passives are mostly translated with active sentences with the direct object in topic position (Tankó 2011, 2014). Furthermore, certain dialectal differences have been pointed out as well. The PVAC is much more frequent in the Csángó and Székely dialects than in standard Hungarian - results confirmed by other studies as well (Kádár and Németh 2010: 201).

\section{The main questions}

In the present study, we will compare the original and translated versions of two well-known novels and address a series of questions as comparing the translation equivalents to the results of previous studies. First of all, we are interested whether the same Hungarian equivalents used for the English passive are used in translations of literary works or translators resort to other, possibly more ingenious solutions, given their thorough knowledge of the source and target languages as compared to common speakers of English as a second language. Another issue to investigate is whether any of the structures enumerated above is preferred in literary translations. Given the fact that one of the two novels under discussion was written in the second half of the $19^{\text {th }}$ century and the other one in the middle of the $20^{\text {th }}$ century, we would expect the archaic synthetic Hungarian passive to be used. The third problem to look into is whether there is a difference between literary translations and everyday speech regarding the choice of an equivalent when conveying the passive meaning.

\section{The hypothesis}

Our main hypothesis is that the equivalents used in literary translations will be basically the same. As expected, synthetic passive will be avoided, while active sentences with the DO in topic will be preferred for short passives and the active sentences with the DO in topic and the subject in focus for the long passives. Another hypothesis is that there will be less PVACs in translations since translations have in mind standard Hungarian. 


\section{The study}

\subsection{Data}

For data collection, we have used the English translation of $A z$ arany ember, written by Mór Jókai in 1872 and translated by Hegan Kennard in 1894 (Timar's two worlds). As Jókai's novel is from the $19^{\text {th }}$ century, we have chosen another piece from the $20^{\text {th }}$ century, that is the first chapter of 1984 , a novel written by George Orwell in 1949 and translated into Hungarian by László Szíjgyártó in 1989. In our choice of these particular novels, we had in mind the fact that these texts contain long descriptive passages, consequently they provide favourable context for the use of passive constructions.

We have compared the two translations with their original versions with respect to the use of passive(like) constructions, identifying and analysing the English passive constructions and their Hungarian equivalents. In our analysis, we have considered only the first chapter of 1984 and its Hungarian version and the first eight chapters of the Hungarian novel and its English translation.

\subsection{Findings in the Hungarian novel}

Being a novel from the $19^{\text {th }}$ century, we have 19 instances of synthetic passive in the original Hungarian text. When the original Hungarian version uses synthetic passive, it is usually translated by an English passive construction (84.21\%).

$$
\begin{array}{ll}
\text { nyilváníttatik (p. 27) } & \text { is declared (p. 5) } \\
\text { elolvastatnak (p. 60) } & \text { are read (p. 27) } \\
\text { visszaadatnak (p. 60) } & \text { are returned (p. 27) }
\end{array}
$$

It is only in three cases where the translator resorted to an active construction instead of the passive.

$$
\begin{array}{ll}
\text { forgattatik (p. 55) } & \text { turn the skewer (p. 23) } \\
\text { felhúzatik (p. 55) } & \begin{array}{l}
\text { to spit on a long skewer in a piece } \\
\text { of beef (p. 23) }
\end{array} \\
\text { nem mondatik semmi (p. 60) } & \text { nothing wrong (p. 27) }
\end{array}
$$

The PVAC appears 54 times in the first seven chapters of the book, and it is translated using an English passive construction 27 times (50\%).

The Hungarian PVAC is totally ignored in three cases and left without any translation whatsoever.

1 The numbers in brackets refer to page numbers. 
(18) tölgyfahajóhoz van kapcsolva (p. 30) [it is joined to the door of oak] rétegekre látszanak osztva (p. 55) [they seem to be split into layers] tüzfényével volt kifestve (p. 58) [it has been painted by the light of fire] ${ }^{2}$

In some cases, the Hungarian PVAC is translated using some adjective, which actually implies an agent having performed some kind of activity in order to reach the resulting state expressed by the adjective.

legkevésbé volt megelégedve (p. 26)

meg volt mentve (p. 50)

not satisfied (p. 4)

rejtve van (p. 70) was safe (p. 19) is least accessible (p.33)

The Hungarian PVAC is translated using an active English construction in 16 cases.
tele van aggatva (p. 29)
hang (p. 6)
el lesz süllyesztve ( $p .38$ )
must go down (p. 12)
le van csúszva (p. 84)
has dropped (p.43)

Table 1. Translation equivalents of the Hungarian archaic passives and PVACs

\begin{tabular}{lll}
\hline English translation & $\begin{array}{l}\text { Archaic } \\
\text { passive \% }\end{array}$ & PVAC \% \\
\hline Passive translation & 84.21 & 50 \\
\hline No translation & - & 5.55 \\
\hline Adjectival translation & - & 14.8 \\
\hline Active translation & 15.7 & 29.62 \\
\hline
\end{tabular}

Finally, let us consider a few examples where the Hungarian PVAC is translated with an English passive construction, which seems to be a rule of thumb.
feketére van festve (p. 28) meg volt mentve (p. 43)
is painted black (p. 6)
meg vannak jutalmazva (p. 62) was saved (p. 15)
are rewarded (p.28)

Summarizing, the translator mostly used the English passive construction in the translation of synthetic passives as well as for the PVACs. However, about a third of the PVACs are translated using active sentences and, marginally, adjectival forms occur too.

2 Our translation. 


\subsection{Findings in the English translation of the Hungarian novel}

A number of 150 passive constructions appear in the English translation: 43 long passives and 107 short passives, that is constructions without an expressed agent.

Table 2. Translation equivalents for the English passive constructions

\begin{tabular}{lll}
\hline Hungarian structure & Long passive \% & Short passive \% \\
\hline Synthetic passive & 2.32 & 10.28 \\
\hline PVAC & 20.93 & 13.08 \\
\hline Active sentence & 76.74 & 71.96 \\
\hline No verbal structure & - & 4.67 \\
\hline
\end{tabular}

Most of the time, the agent is expressed in a BY-phrase, yet there are cases when we come across WITH-phrases which could be interpreted as agents.

(the ground) was covered with grass (p. 35)

(it) is covered with vines ( $p .36$ )

(the rooms) are roofed with rushes (p. 36) füvel van benóve ( $p .73)$

be van futtatva (p. 74)

náddal van födve (p. 74)

About a fifth of the 43 English long passives appear as counterparts of the Hungarian PVAC. It is interesting that all of them are formed using the BE auxiliary as opposed to what we have expected: a structure with the BECOME auxiliary.

(23) is marked by two arrows (p. 15)

is surrounded by an earthwork ( $p .30$ )

was fastened to it by a hook (p. 22) meg van jelölve (p. 42)

a szádához vannak ragasztva (p. 66)

a deszkához volt akasztva (p. 54)

In one case, the English passive construction translates a Hungarian synthetic passive.

are taken by the inspector (p. 26)

átvétetnek (p. 60)

The rest of the English long passive constructions are used for translating active sentences (around $76 \%$ of the cases).
is divided by a ledge of rock ( $p .17)$
was held by winged genii ( $p .30)$
zárja el (p. 46)
was hidden by a long ugly island (p.32)
tartja (p. 65)
elfedi (p. 69) 
In the case of 5 short passive forms, there is no Hungarian equivalent in the original version; the translator might have introduced them to offer a clearer picture to the English reader.

(26) (salt, tobacco and coffee) are smuggled (p. 5)

(the papers) are well smoked (p.60)

(gentle softness) is spread (p. 84)

Other English short passive constructions are used for translating synthetic passives in 11 cases.

$\begin{array}{ll}\text { is declared infected (p. 5) } & \text { nyilvánittatik (p. 27) } \\ \text { has been found (p. 28) } & \text { nem találtatott ( } p .61) \\ \text { are delivered (p. 28) } & \text { beküldetnek (p. 62) }\end{array}$

Many of the English short passive constructions are used for translating regular active sentences (77 occurrences representing 71.96\%).
was seen (p. 22)
meglátták (p. 53)
was exhausted (p. 33)
elfogyott (p. 69)
was intended ( $p .33)$
ajándékba szánta (p. 69)

Some of the long passives are used as counterparts of the Hungarian PVAC (14 cases).

$$
\begin{array}{ll}
\text { is painted black (p. 6) } & \text { feketére van festve (p. 28) } \\
\text { was saved (p. 15) } & \text { meg volt mentve (p. 43) } \\
\text { is stuck (p. 36) } & \text { a sziklához van ragasztva (p. 74) }
\end{array}
$$

Summarizing, in over $70 \%$ of the occurrences, English passives, long or short, are used for translating regular active sentences, which clearly signals that passive is far more frequent and productive in English than in Hungarian (compare 19 synthetic passives and 54 PVACs in the original Hungarian text to 150 passive forms in the English translation).

\subsection{Findings in the English novel}

A number of 304 passive constructions appear in the English translation: 26 long passives and 278 short passives, as shown in Table 3 below. 
Considering the long passive constructions, it is interesting that only one of the 26 occurrences is translated into Hungarian with an active sentence in which the DO is in topic.

(30) his skin was roughened by coarse soap (p. 2)

börét kicserzette a durva szappan ( $p .3$ )

Three of the English long passive constructions are translated into Hungarian using the $3^{\text {rd }}$ person plural form with generic reading.

(31) could be shown by documentary evidence (p. 27) támasztották alá (p. 22) were composed by mechanical means (p. 30) készítettek (p. 23) had been oppressed by the capitalists ( $p .49) \quad$ elnyomták (p. 38)

Table 3. Translation equivalents for the English passive constructions in 1984

\begin{tabular}{lll}
\hline Hungarian translation & $\begin{array}{l}\text { Long } \\
\text { passive \% }\end{array}$ & $\begin{array}{l}\text { Short } \\
\text { passive \% }\end{array}$ \\
\hline Synthetic passive & - & 0.35 \\
\hline PVAC & - & 3.95 \\
\hline Generic translation & 11.53 & 45.32 \\
\hline Active sentence, DO in topic & 3.84 & 3.95 \\
\hline Regular active sentence & 84.61 & 42.8 \\
\hline Other solution & - & 3.23 \\
\hline No translation & - & 0.35
\end{tabular}

The other passive constructions (more exactly 22 cases) are translated with regular Hungarian active structures.

(32) were roamed by gorilla-faced guards (p. 3) gorillaarcú ôrök cirkáltak (p.4) had been adopted by the Ministry of Peace (p. 32) el is fogadott (p. 25) are not paralysed by fright ( $p .71$ ) nem bénítja is meg (p. 54)

In the case of one short passive form, there is no Hungarian equivalent in the translation.

(33) (Goldstein himself) had been seen there (p. 38)

In another case, the short passive is translated using the Hungarian synthetic passive. Expectedly, we are dealing with a verb that is typically used in the synthetic passive form in contemporary Hungarian (születik 'be born' from szül 'give birth'). 
született (p. 6)

Other English short passive constructions are translated using the Hungarian PVAC (in 11 cases).
was wound (p. 7)
a dereka köré tekerve (p. 7)
was written ( $p .7)$
volt az arcára írva (p. 7)
was plastered (p. 47)
vastagon volt az arcára kenve (p. 37)

In other 11 cases, English short passive constructions are translated using active Hungarian constructions with the direct object in topic position.
was overheard (p. 2)
was scrutinized (p. 2)
minden hangját hallják (p. 4)
was thrown back (p. 37)
minden mozdulatát megfigyelik ( $p .4)$
fejét hátravetette (p. 29)

Many of the English short passive constructions (around 45\%) are translated with regular active sentences with generic reading, where the verb is in the $3^{\text {rd }}$ person plural form.
were supposed (p. 61)
a párttagokról feltételezték (p. 47)
had been condemned (p. 8)
halálra ítélték (p. 8)
were nicknamed (p. 26)
becézték (p. 21)

A great number (about $42 \%$ ) of the short passives were translated using regular active Hungarian sentences.

$$
\begin{aligned}
& \text { had been grouped (p. 23) } \\
& \text { would be whirled away (p. 26) } \\
& \text { was refused (p. 45) }
\end{aligned}
$$

$$
\begin{aligned}
& \text { csoportosult (p. 19) } \\
& \text { sodorta le (p. 21) } \\
& \text { megtagadta (p. 36) }
\end{aligned}
$$

Beyond the expected Hungarian translation equivalents of the English passive construction, there are some other solutions as well. We have come across some interesting choices in translation which disregarded all the possible Hungarian equivalents of the English passive and provided original solutions. For example, 'was said' is translated with 'állítólag' [supposedly/allegedly] or 'a szóbeszéd szerint' [rumour has it] ${ }^{3}$.

$$
\begin{aligned}
& \text { was said (p. 3) } \\
& \text { was said (p. 38) }
\end{aligned}
$$

állítólag (p. 4)

a szóbeszéd szerint (p. 30) 
Another interesting solution is the use of nouns when translating English passive constructions into Hungarian, as illustrated in the examples below. This shift in word class, i.e. from verb to noun in our case, is known in the literature as transposition (Molina and Hurtado Albir 2002).

$$
\begin{aligned}
& \text { the flats were built (p.4) } \quad \text { a lakás tervezói (p. 5) [the designers of the flats] } \\
& \text { a jargon was used (p. 26) } \\
& \text { tolvajnyelven (p. 21) [in jargon] }{ }^{4}
\end{aligned}
$$

Summing up, when translating English passive constructions into Hungarian, the translator mostly uses active sentences. These result support Klaudy's (2003: 177) theory that Indo-European languages tend to be more static as compared to the more dynamic Hungarian with less passive constructions. Consequently, the Hungarian synthetic passive and the PVAC appear only sporadically. We have noted some unusual nominal and adverbial solutions as well, which sound very natural in Hungarian.

\section{Conclusions, limitations, directions for further research}

In the present paper, we have explored the problems translators face when dealing with English passive constructions. We have argued that the number of Hungarian equivalents used for the English passive in translations of literary works is about the same as the ones used in everyday speech, as presented in previous studies (Tankó 2011, 2014). However, a few interesting solutions occurred, e.g. the use of nouns in certain cases. As for choosing among the equivalents in translating the English passives, active sentences seem to be preferred in literary translations, while PVAC is less frequent. This result supports our hypothesis: since translations imply the use of standard Hungarian, PVACs are less frequent in translations. As expected, Hungarian synthetic passive is avoided in translation.

Due to spatial constraints, we have dealt only with a few chapters of the discussed novels; furthermore, we have omitted discussing the non-predicative passive forms. Consequently, further research is needed to investigate strategies for translating passives and passive-like constructions throughout the two novels and, possibly, involving translations of contemporary pieces of literature so as to have a wider picture on the Hungarian equivalents of the English passive in literary translations. 


\section{References}

Alberti, Gábor. 1996. Model Tau: a formal theory of thematic roles. In: Zoltán Bánréti (ed.), Papers in the theory of grammar, 184-235. Budapest: Institute for Linguistics, Academy Press.

1998. On passivization in Hungarian. In: de Groot, Casper, Kenesei, István (eds), Papers from the Amsterdam Conference. Approaches to Hungarian 6: 105-121. Szeged: JATE Press.

Bartos, Huba. 2009. The syntax of Hungarian va- adverbial participles. A single affix with variable merge-in locations. In: Katalin, É. Kiss (ed.), Adverbs and adverbial adjuncts at the interfaces, 75-102. Berlin: Mouton de Gruyter.

É. Kiss, Katalin. 2008. Topic and focus: two structural positions associated with logical functions in the left periphery of the Hungarian sentence. Acta Linguistica Hungarica 55: 287-296.

Jókai, Mór. 1967. Az arany ember [The Golden Man]. Bukarest: Ifjúsági Könyvkiadó.

Kennard, Hegan. 1894. Timar's two worlds. Edinburgh and London: Blackwood. Available digital version: http://www.archive.org/details/ timarstwoworlds00jkrich, last visited on 10 June 2016.

Kádár, Edit-Németh, Boglárka. 2009. Predikatív határozói igeneves szerkezetek csángó beszélt nyelvi szövegekben [The predicative verbal-adverbial constructions in Csángó spoken texts]. In: Katalin, É. Kiss, Hegedűs, Attila (eds), Nyelvelmélet és dialektológia [Language theory and dialectology], 189212. Piliscsaba: Pázmány Péter Katolikus Egyetem.

2010. The role of the predicative participle construction in the csángó tenseaspect system. Philobiblon 15: 194-225.

Kertész, Judit. 2005. Eseményszerkezet, aspektus, mondatszerkezet. A predikatív határozói igenevek, [Event structure, aspect, clause structure: the predicative adverbial participles]. PhD dissertation. Budapest: Eötvös Lóránd University.

Klaudy, Kinga. 2003. Languages in translation. Lectures on the theory, teaching and practice of translation. With illustrations in English, French, German, Russian and Hungarian. Budapest: Scholastica.

Márkus, Andrea. 2008. Participles and the passive in Hungarian. MA thesis. Budapest: Eötvös Lóránd University.

Molina, Lucia-Hurtado Albir, Amparo. 2002. Translation techniques revisited: a dynamic and functionalist approach. Translators' Journal 47: 498-512.

Németh, Boglárka. 2007. Participiul rezultativ-predicativ. O abordare aspectuală [The predicative verbal adverbial construction. An aspectual view]. MA thesis. Cluj-Napoca: Babeş-Bolyai University.

Orwell, George. 1949. 1984. Available at: https://archive.org/details/ Orwell1984preywo, last visited on $10^{\text {th }}$ June 2016. 
1989. 1984. [Hungarian translation by László Szíjgyártó]. Available at: http:// mek.oszk.hu/00800/00896/, last visited on 10 June 2016.

Tankó, Enikő. 2011. The Acquisition of the English passive construction by L1 speakers of Hungarian. PhD thesis. Bucharest: University of Bucharest.

2014. L2 romanian influence in the acquisition of the English passive by L1 speakers of Hungarian. Acta Universitatis Sapientiae, Philologica 6 (2): 227-248. Tóth, Ildikó. 2000. Va- and ván- participles in Hungarian. In: Alberti, Gábor, Kenesei, István (eds), Papers from the Pécs Conference. Approaches to Hungarian 7: 237-256. Szeged: JATE Press. 